\title{
Aerosol meteorology of the Maritime Continent for the 2012 7SEAS southwest monsoon intensive study - Part 1: regional-scale phenomena
}

\author{
Jeffrey S. Reid ${ }^{1}$, Peng Xian ${ }^{1}$, Brent N. Holben ${ }^{2}$, Edward J. Hyer ${ }^{1}$, Elizabeth A. Reid ${ }^{1}$, Santo V. Salinas ${ }^{3}$, \\ Jianglong Zhang ${ }^{4}$, James R. Campbell ${ }^{1}$, Boon Ning Chew ${ }^{5}$, Robert E. Holz ${ }^{6}$, Arunas P. Kuciauskas ${ }^{1}$, Nofel Lagrosas ${ }^{7}$, \\ Derek J. Posselt ${ }^{8}$, Charles R. Sampson ${ }^{1}$, Annette L. Walker ${ }^{1}$, E. Judd Welton ${ }^{2}$, and Chidong Zhang ${ }^{9}$ \\ ${ }^{1}$ Marine Meteorology Division, Naval Research Laboratory, Monterey, CA, USA \\ ${ }^{2}$ NASA Goddard Space Flight Center, Greenbelt, MD, USA \\ ${ }^{3}$ Centre for Remote Imaging Sensing and Processing, National University of Singapore, Singapore \\ ${ }^{4}$ Dept. of Atmospheric Science, University of North Dakota, Grand Forks, ND, USA \\ ${ }^{5}$ Meteorological Service, Singapore \\ ${ }^{6}$ Space Sciences Engineering Center, University of Wisconsin, Madison, WI, USA \\ ${ }^{7}$ Manila Observatory, Manila, Philippines \\ ${ }^{8}$ Jet Propulsion laboratory, Pasadena, CA, USA \\ ${ }^{9}$ NOAA Pacific Marine Environmental Laboratory Seattle, WA, USA
}

Correspondence to: Jeffrey S. Reid (jeffrey.reid@nrlmry.navy.mil)

Received: 11 March 2016 - Published in Atmos. Chem. Phys. Discuss.: 25 April 2016

Revised: 2 September 2016 - Accepted: 2 October 2016 - Published: 15 November 2016

\begin{abstract}
The largest 7 Southeast Asian Studies (7SEAS) operation period within the Maritime Continent (MC) occurred in the August-September 2012 biomass burning season. Included was an enhanced deployment of Aerosol Robotic Network (AERONET) sun photometers, multiple lidars, and field measurements to observe transported smoke and pollution as it left the MC and entered the southwest monsoon trough. Here we describe the nature of the overall 2012 southwest monsoon (SWM) and biomass burning season to give context to the 2012 deployment. The MC in 2012 was in a slightly warm El Niño/Southern Oscillation (ENSO) phase and with spatially typical burning activity. However, overall fire counts for 2012 were $10 \%$ lower than the Reid et al. (2012) baseline, with regions of significant departures from this norm, ranging from southern Sumatra $(+30 \%)$ to southern Kalimantan $(-42 \%)$. Fire activity and monsoonal flows for the dominant burning regions were modulated by a series of intraseasonal oscillation events (e.g., Madden-Julian Oscillation, or MJO, and boreal summer intraseasonal oscillation, or BSISO). As is typical, fire activity systematically progressed eastward over time, start-
\end{abstract}

ing with central Sumatran fire activity in June related to a moderately strong MJO event which brought drier air from the Indian Ocean aloft and enhanced monsoonal flow. Further burning in Sumatra and Kalimantan Borneo occurred in a series of significant events from early August to a peak in the first week of October, ending when the monsoon started to migrate back to its wintertime northeastern flow conditions in mid-October. Significant monsoonal enhancements and flow reversals collinear with tropical cyclone (TC) activity and easterly waves were also observed. Islands of the eastern MC, including Sulawesi, Java, and Timor, showed less sensitivity to monsoonal variation, with slowly increasing fire activity that also peaked in early October but lingered into November. Interestingly, even though fire counts were middling, resultant AERONET $500 \mathrm{~nm}$ aerosol optical thickness (AOT) from fire activity was high, with maximums of 3.6 and 5.6 in the Sumatra and Kalimantan source regions at the end of the burning season and an average of $\sim 1$. AOTs could also be high at receptor sites, with a mean and maximum of 0.57 and 1.24 in Singapore and 0.61 and 0.8 in Kuching Sarawak. Ultimately, outside of the extreme 2015 
El Niño event, average AERONET AOT values were higher than any other time since sites were established. Thus, while satellite fire data, models, and AERONET all qualitatively agree on the nature of smoke production and transport, the MC's complex environment resulted in clear differences in quantitative interpretation of these datasets.

\section{Introduction and background}

The Maritime Continent (MC) hosts one of the most complicated coupled systems on Earth. The intricate feedbacks between tropical meteorology, land surface, and oceans are complex and a challenge to understand and simulate. Indeed, early findings of the Coordinated Regional Climate Downscaling Experiment (CORDEX; http://www.cordex. org/; Giorgi et al., 2012) yielded diverging climate model simulations for the Southeast Asian region. Strong biases in temperature and large uncertainties in precipitation estimates have been diagnosed (Jamandre and Narisma, 2013). Atmospheric models have difficulty representing complex tropical waves in the MC on scales ranging from Kelvin waves through the Madden-Julian Oscillation (MJO) and the regional monsoon (e.g., Misra and Li, 2014; Zhang, 2014). Owing to its dependence on meteorology, the MC's aerosol system is likewise complex, with the added challenge of persistent high clouds obscuring satellite remote sensing observations of aerosol life cycle (Reid et al., 2013; Campbell et al., 2016). Field measurements in the MC are difficult to obtain in this part of the globe and likewise to quality assure in a complex sampling environment. Ultimately, the high degree of variability in the MC's aerosol environment poses great observational and modeling challenges for determining how aerosol particles, weather, and climate relate.

Given the above research challenges inherent in the MC's environment, the 7 Southeast Asian Studies (7SEAS) program was motivated to improve the ability of the community to observe and analyze aerosol and meteorology interactions in the region (e.g., Reid et al., 2012, 2013; Lin et al., 2013). The role of El Niño/Southern Oscillation (ENSO) in regional drought and subsequent feedback into biomass burning has long been a focus of the aerosol community's efforts for the MC's aerosol environment (e.g., Nichol, 1998; Field and Shen, 2008). However, while ENSO is clearly a strong interseasonal modulator of burning activity, biomass burning is important in all years (Reid et al., 2012). Further, if we wish to understand how aerosol particles, weather, and climate interact, much finer-scale phenomena than ENSO require investigation. The aerosol system is of course dependent on meteorology, and this meteorology is defined by the complicated interplay between such phenomena as the MJO and/or boreal summer intraseasonal oscillation (BSISO), equatorial waves, tropical cyclones (TCs), and even features as fine as boundary layer dynamics and land-sea breezes (e.g., Reid et al., 2012, 2015; Atwood et al., 2013; Campbell et al., 2013; Guo et al., 2013; Wang et al., 2013; Xian et al., 2013; Ge et al., 2014). At the same time, to infer aerosol impacts on radiation, clouds, and climate, meteorological context in relation to these phenomena must be taken into account.

7SEAS has worked to encourage networks and intensive measurements throughout Southeast Asia and integrate these measurements into conceptual and numerical models of the aerosol system. Although all seasons and regions throughout Southeast Asia are of interest to the 7SEAS program, within the MC, 7SEAS field measurements and life cycle studies have focused on the southwest monsoon (SWM) biomass burning season in Indonesia and Malaysia, with Singapore and the Philippines as key receptor sites (e.g., Reid et al., 2012, 2015; Atwood et al., 2013; Chew et al., 2011, 2013; Salinas et al., 2013; Xian et al., 2013; Wang et al., 2013; Yang et al., 2013). The year 2012 was a high water mark for 7SEAS efforts in the MC, with over 15 Aerosol Robotic Network (AERONET; Holben et al., 1998) sun photometers and five Micro-Pulse Lidar Network (MPLNET) lidars on station. Additional intensive measurements were made in Singapore, as well as on a vessel stationed in the Palawan Archipelago as a receptor. Taken together, these sites provided some of the first measurements of natural, industrial, and biomass-burning-influenced air masses that transited the South China and Sulu seas on their way into the SWM trough (Atwood et al., 2016; Reid et al., 2016).

To support the 2012 7SEAS MC effort, and in particular the Palawan research cruise, this paper is the first of two that present an analysis of the many scale dependencies of the MC's aerosol meteorology. The focus of Part I is the regional-scale phenomena, such as ENSO, MJO, monsoon enhancements, and TCs, and how they relate to biomass burning activity and transport. Our purpose is to give context to the 2012 effort, examine how 2012 compares to other seasons in regard to overall fire and monsoonal activity, and try to provide an overall narrative to 2012 aerosol meteorology. With the benefit of the research vessel observations from the 2012 deployment, we leave results related to finer-scale phenomena such as squall lines and sea breeze fronts to Part 2 of this pair of papers (Reid et al., 2016).

\section{Analysis data}

The SWM burning season generally runs from June through October (Reid et al., 2012), with a peak in September and October. The core 2012 7SEAS study period was August through September 2012 and is the focus here. Data for these analyses come from three categories: observations including surface-based aerosol optical thickness (AOT) from AERONET, thermodynamic structure from radiosondes, satellite-based remote sensing including Moderateresolution Imaging Spectrometer (MODIS) AOT and active fire hotspots, as well as multi-sensor precipitation; and mod- 


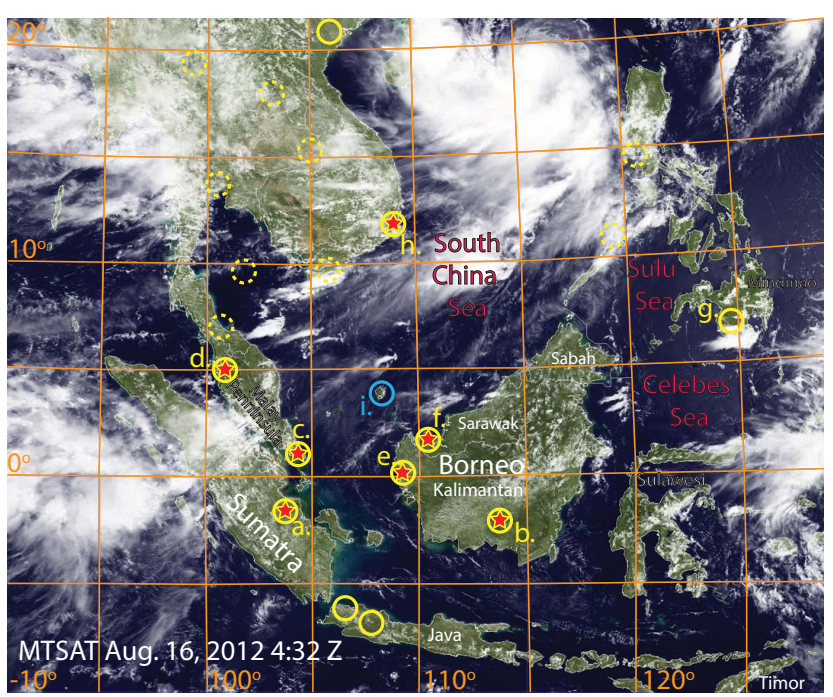

Figure 1. Map of network sites for the 2012 7SEAS southwest monsoon intensive. Included are AERONET sites used in this analysis (yellow circles), other AERONET sites (dashed yellow circles), and MPLNET sites (red stars). Sites are (a) Jambi; (b) Palangkaraya; (c) Singapore; (d) Tahir; (e) Pontianak; (f) Kuching; (g) Notre Dame of Marbel University, Mindanao; and (h) Nha Trang. Also marked is the Riau Island radiosonde site (blue circle, $\mathrm{i}$ ).

eling based on global US Navy meteorology and aerosol systems. All of the products used are considered operational and thus are only briefly outlined here.

\subsection{Observations}

The maximum extent of 7SEAS aerosol observations throughout the MC occurred during the 2012 SWM season. Specifically relevant to the analysis of 2012, over 15 AERONET sun photometers were in operation, with start dates from mid- to late July through October. Of these, eight were of particular use for evaluating the biomass burning season. Locations are displayed in Fig. 1, overlaid on an MTSAT false color image for 16 August 2012, representative of one of the clearer periods during the biomass burning. Identified are AERONET sites (circles) for the following sites: (a) Jambi, Sumatra, and (b) Palangkaraya, southern Kalimantan in the core biomass burning source regions of Indonesia; (c) Singapore; (d) Tahir, Malay Peninsula, Malaysia; (e) Pontianak, western Kalimantan, and (f) Kuching, Sarawak, as key coastal exit sites; and (g) Notre Dame of Marbel University, Mindanao, and (h) Nha Trang, Vietnam, as outer boundaries and receptors. While there are many other sites in the region, they are not used here because of excessive high cloud cover or instrumentation failure (these are marked as dashed circles). Although not analyzed here, for completeness MPLNET sites are marked (stars).

To track overall smoke or pollution transport, we utilize the AERONET operational $500 \mathrm{~nm}$ daily averaged fine-mode
AOT derived from Level 2.0 Spectral Deconvolution Algorithm (SDA) Version 4.1 (O'Neill et al., 2003). Use of the SDA to separate fine- and coarse-mode extinction or optical depth has been verified (Kaku et al., 2014). SDA is particularly beneficial as it allows us to track fine-mode particles, such as from biomass burning or anthropogenic sources, while at the same time removing the influence of thin cirrus contamination, which can be large in this region (Chew et al., 2011). Given the wavelength dependencies for biomass burning particles in the region, $500 \mathrm{~nm}$ AOT is approximately $10-15 \%$ higher than $550 \mathrm{~nm}$ AOT used in MODIS.

A second dataset used here is the radiosonde releases at Riau Island north of Borneo (Fig. 1 - location i) to gauge the strength of the SWM. Data used here were hand evaluated to remove clear reporting errors. Most importantly, we employed the $925 \mathrm{hPa}$ meridional wind to track monsoonal strength and transition. This metric was used in overarching fire meteorology analyses of Reid et al. (2012) as suggested in the monsoonal analysis paper of Lu and Chan (1999). Also from this Riau Island radiosonde site we used the $700 \mathrm{hPa}$ relative humidity field. As discussed in Reid et al. (2015), this metric is indicative of the advection of drier air from the Indian Ocean that has a tendency to cap regional convection. In practice we have found this metric in particular to be a good predictor of convection (moist convection is more convectively active; dry convection is suppressed). To smooth transients, a 3-day boxcar average was applied. Also, for TC fixes and intensities we utilized the Joint Typhoon Warning Center best track and statistics from the Automated Tropical Cyclone Forecast system (ATCF; Sampson and Schrader, 2000).

\subsection{Satellite data}

For satellite monitoring of biomass burning, MODIS active fire hotspot analysis was utilized, integrated in the analysis structure of Reid et al. (2012, 2015), with context as laid out in Hyer et al. (2013). In addition to fire we also utilized NASA MODIS Collection 6 Level 3 data from monitoring AOT (Levy et al., 2013). As discussed in Reid et al. (2013), all satellite aerosol products suffer from a host of cloud contamination and sampling issues. For evaluating aerosol transport extent, Terra MODIS is preferable due to the generally lower fractions of cloud cover in the AM orbit. This said, the current version of Terra MODIS AOT also suffers from instrument and calibration issues. Hence, we only use the data in a semi-quantitative manner.

Other various datasets are also used, including geostationary MTSAT satellite products as found on the NEXSAT website, which were examined for the study period to help provide context to day-to-day variability in meteorology (visible, infrared, cloud heights, scatterometer, etc.; Miller et al., 2006; http://www.nrlmry.navy.mil/nexsat-bin/nexsat. cgi). Daily precipitation was monitored using Climate Pre- 
diction Center (CPC) MORPHing product (CMORPH; Joyce et al., 2004).

\subsection{Model data}

Model data are used to provide a larger contextual understanding of the regional metrological and aerosol environment. To be consistent with the analyses of Reid et al. (2012, 2013, 2015), the Navy Global Atmospheric Prediction System (NOGAPS; Hogan and Rosmond, 1991) is used to provide baseline meteorological data for analyses as well as to drive offline Navy Aerosol Analysis and Prediction System (NAAPS) aerosol simulations. While NOGAPS horizontal resolution is $\sim 0.5^{\circ}$ in this region, spectral files were truncated to $1^{\circ} \times 1^{\circ}$ for modeling aerosol transport for this season in a configuration consistent with the NAAPS reanalysis (Lynch et al., 2016). In NAAPS, four species are simulated: dust, biomass burning smoke, fine anthropogenic/biogenic, and sea salt. In the reanalysis configuration, smoke fluxes are driven from the MODIS smoke source function drawn from a MODIS-only version of the Fire Locating and Monitoring of Burning Emissions (FLAMBE; Reid et al., 2009). To improve wet deposition, CMORPH precipitation is used to constrain scavenging Xian et al. (2009). Data assimilation includes MODIS AOT and MISR (Zhang et al., 2008), although there are few data-assimilation-grade AOT retrievals in this part of the world. Nevertheless, NAAPS capability for smoke characterization in the Maritime Continent region has been demonstrated (e.g., Hyer and Chew, 2010; Reid et al., 2012, 2015; Xian et al., 2013) and has been further improved upon in the reanalysis version used here. For this overview paper, we simply utilize fine NOGAPS winds and AOT analyses to map smoke, transport, and pollution extent.

\section{Results}

For the analysis of the regional meteorology in the 2012 burning season, we break the problem down into a number of subsections. First, we describe the overall fire and monsoonal activity for 2012 (Sect. 3.1). Second, we examine the time series of fire activity and monsoonal meteorology for the 2012 monsoon season (Sect. 3.2). Finally, we examine the variability in AOT throughout the region to assess overall smoke patterns and transport behavior (Sect. 3.3).

\subsection{Overall fire and monsoon characteristics}

The SWM in the South China Sea (SCS) typically starts in late April to early May, with flow reversal to northeast monsoon in mid-October (Lu and Chan 1999; Chang et al., 2005; Moron et al., 2009; Reid et al., 2012). Thus, climatologically, the SWM is in full existence from June through September. In regards to precipitation, drier periods in the MC start in Sumatra and propagate eastward over time (Moron et al., 2009). Based on MODIS active fire hotspot data, and as dis-

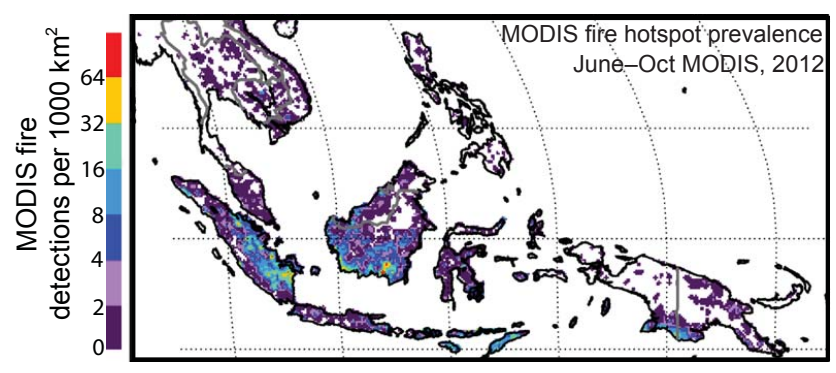

Figure 2. Overall Terra and Aqua MODIS detected fire prevalence for June through October 2012.

cussed in the time series analysis in Sect. 3.2, the first significant fire events did not begin until June, with region-wide initiation not beginning until August, which is typical for the region (Reid et al., 2012). Fire activity largely diminishes with the monsoon reversal in early October, with lingering fire activity in the eastern MC lasting through October. Here we will briefly review these features.

\subsubsection{Overall fire activity}

Figure 2 presents an overall fire prevalence map constructed from combined Terra and Aqua MODIS active fire hotspot detections for 1 June through 31 October 2012. Fire counts by island, region, or province as defined in the 2003-2009 baseline paper of Reid et al. (2012) are provided in Table 1. Overall fire patterns and activity are highly correlated with the spatial map fire count baseline of Reid et al. (2012). Although there is some fire activity over the entire domain, the most significant areas of activity include central Sumatra (9135 fires), southern Sumatra (12241 fires), and southern Kalimantan (8120 fires). For 2012 the June-November primary burning season accounted for $99 \%$ of these fires, although local but significant fire outbreaks occurred all year round. Other significant burning includes eastern and western Kalimantan at 1571 and 5721 fires each. Islands such as Java and Timor can also have significant fire prevalence.

From Table 1, overall MC fire counts from MODIS for 2012 were $12 \%$ lower than the 2003-2009 baseline. Given the complexities of fire observation and the significant interannual standard deviations of fire prevalence in the region (generally $>50 \%$; Reid et al., 2012), we consider this an overall "average" fire season. The most notable enhancements from the norm was in southern Sumatra and western Kalimantan with a $30 \%$ enhancement. Rates in the fireprone eastern and southern Kalimantan were markedly down in 2012 , by roughly $40 \%$.

The MODIS fire data suggest that $95 \%$ of fire activity was in the June-October burning season and roughly $1 \mathrm{cu}-$ mulative standard deviation of the fire activity on Sumatra and Borneo occurred in August and September in particular (Table 1). This period was at the core of the SWM period and also corresponded to the peak of the field activity. For 
Table 1. 2012 Active fire hotspot prevalence from combined Terra and Aqua MODIS for key areas of the Maritime Continent. Included is the 2003-2009 average from Reid et al. (2012), the sum of all fire detections in 2012, the number in the June-October study period here, and the fraction of the 2012 total thereof.

\begin{tabular}{|c|c|c|c|c|c|}
\hline Location & $\begin{array}{r}\text { Average annual } \\
\text { prevalence (no. } \text { year }^{-1} \text { ) } \\
\pm \text { fractional SD }\end{array}$ & $\begin{array}{r}\text { Annual } \\
\text { prevalence } \\
\left(\text { no. year }^{-1}\right) \text {, } \\
2012\end{array}$ & $\begin{array}{r}2012 \text { : climatological average } \\
(\%)\end{array}$ & $\begin{array}{r}\text { Jun-Oct } \\
\text { fire count } 2012\end{array}$ & $\begin{array}{r}\text { Jun-Oct } \\
(\%)\end{array}$ \\
\hline Brunei & $55 \pm 50 \%$ & 60 & 109 & 55 & 92 \\
\hline \multicolumn{6}{|l|}{ Indonesia } \\
\hline Java and Bali & $2120 \pm 21 \%$ & 2157 & 102 & 2049 & 95 \\
\hline Kalimantan, eastern & $3085 \pm 52 \%$ & 1571 & 51 & 1400 & 89 \\
\hline Kalimantan, southern & $13892 \pm 91 \%$ & 8120 & 58 & 8021 & 99 \\
\hline Kalimantan, western & $5370 \pm 59 \%$ & 5742 & 107 & 5720 & 100 \\
\hline Maluku Islands & $890 \pm 58 \%$ & 775 & 87 & 638 & 82 \\
\hline Papua & $2460 \pm 80 \%$ & 2139 & 87 & 1146 & 54 \\
\hline S. Islands and Timor & $3985 \pm 21 \%$ & 4088 & 103 & 3516 & 86 \\
\hline Sumatra, central & $10990 \pm 68 \%$ & 9135 & 83 & 9082 & 99 \\
\hline Sumatra, northern & $210 \pm 32 \%$ & 221 & 105 & 219 & 99 \\
\hline Sumatra, southern & $9400 \pm 78 \%$ & 12241 & 130 & 12166 & 99 \\
\hline Sumatra, westward & $1760 \pm 35 \%$ & 1943 & 110 & 1928 & 99 \\
\hline Sulawesi & $3430 \pm 53 \%$ & 2113 & 62 & 1718 & 81 \\
\hline Subtotal & $57592 \pm 75 \%$ & 50245 & 87 & 47603 & 95 \\
\hline \multicolumn{6}{|l|}{ Malaysia } \\
\hline Malay Peninsula & $1550 \pm 55 \%$ & 1206 & 78 & 1163 & 96 \\
\hline Sabah, Borneo & $640 \pm 43 \%$ & 326 & 51 & 318 & 98 \\
\hline Sarawak, Borneo & $1982 \pm 64 \%$ & 2557 & 129 & 2496 & 98 \\
\hline Subtotal & $4172 \pm 59 \%$ & 4089 & 98 & 3977 & 97 \\
\hline Papua New Guinea & $5170 \pm 52 \%$ & 4487 & 87 & 2935 & 59 \\
\hline Timor Leste & $1120 \pm 21 \%$ & 856 & 76 & 787 & 92 \\
\hline
\end{tabular}

the remainder of this section, we therefore focus on these 2 months.

\subsubsection{Overall monsoonal meteorology}

Meteorology and MODIS AOT data for August and September 2012 are provided in Fig. 3. Included in Fig. 3 are (a) overall NOGAPS-derived monsoonal flow at the surface and $700 \mathrm{hPa}$, overlaid on CMORPH satellite precipitation; (b) likewise monthly anomalies based on the NAAPSReanalysis dataset for 2002-2014; (c) MODIS Terra MOD08 average cloud cover; (d) MODIS Terra MOD08 $550 \mathrm{~nm}$ AOT; and (e) NAAPS fine-mode AOT. As is typical, south of the Equator, surface winds are southeasterly, wrapping around the islands of Borneo and Sumatra to become southwesterly in the SCS. Over the SCS, winds are also largely typical: southwesterly at the surface and veering to zonal by $700 \mathrm{hPa}$. Precipitation gradually increases from the south to the north, with a maximum east of the Philippines in association with the summertime monsoonal trough. In August, there were two precipitation maxima, one along the west coast of Luzon, Philippines, and the other along the west coast of the northern part of Malay Peninsula, both related to the monsoon flows impinging upon the coastal terrains (e.g., Cruz et al., 2013). Another notable cloud and precipitation enhancement is west of Sumatra, in association with a local vorticity maximum as winds transition from easterly to westerly (Wu et al., 2009; Reid et al., 2012). In September, maximum precipitation became zonally elongated from the Bay of Bengal through the SCS to east of the Philippines. This was related partially to the overall summertime monsoonal trough and partially to an MJO event that passed through the MC (see Sect. 3.2.1). MODIS cloud cover is spatially correlated with precipitation, ranging from over $50 \%$ in southern Borneo to near $100 \%$ around Luzon. In general cloud cover is over $70 \%$ throughout the monsoon.

There were other clear differences in the meteorology depicted in Fig. 3 between August and September. Notably, in August winds were characteristically easterly south of the Equator, southerlies across the Equator, and ultimately leading to southwesterly in the SCS. However, in September winds in the lower free troposphere had stronger zonal 


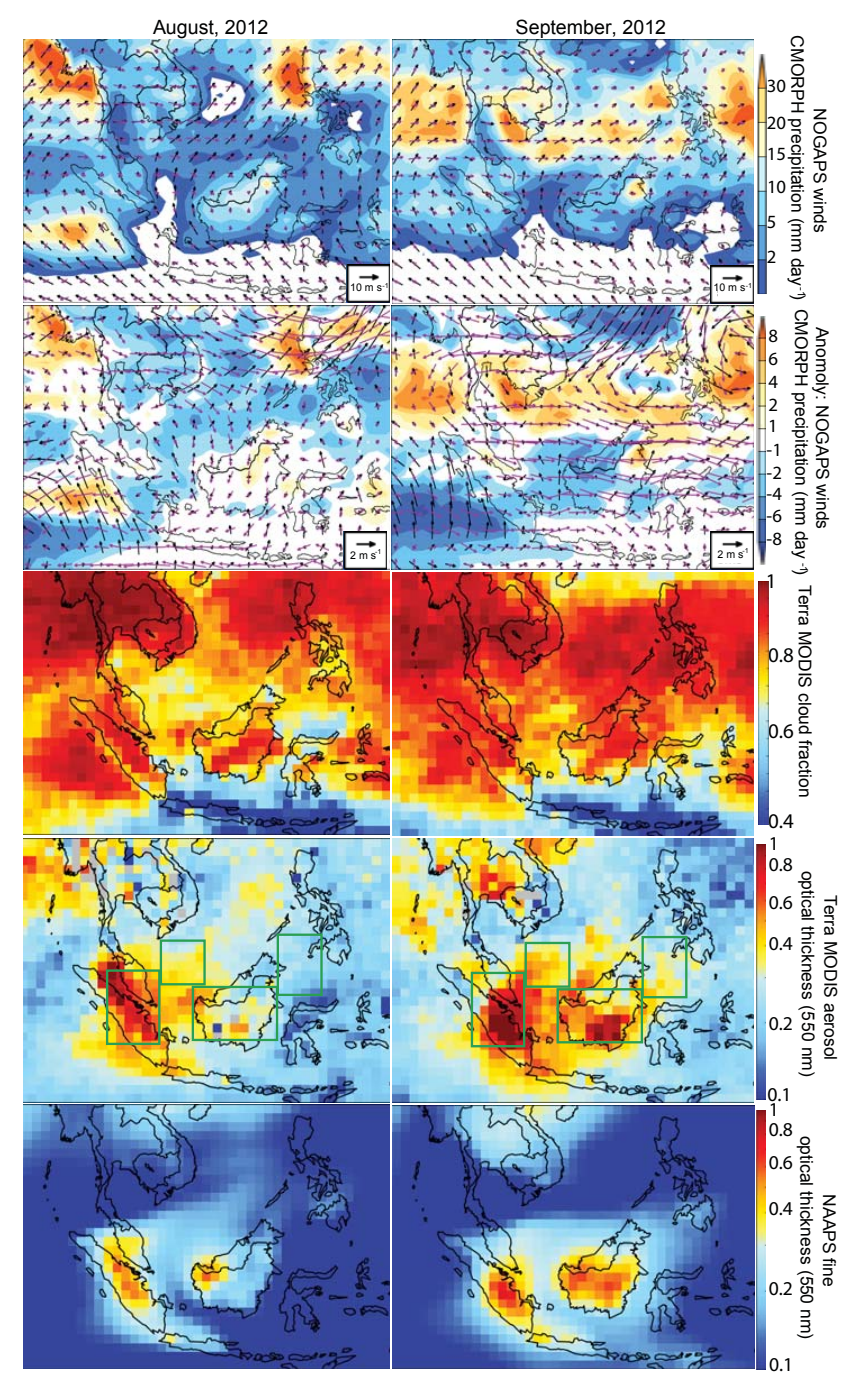

Figure 3. August and September 2012 averages of key fields to represent the overall nature of the southwest monsoon during the 7SEAS intensive. Included are NOGAPS surface (black) and $700 \mathrm{hPa}$ (magenta) winds overlaid on average CMORPH-derived rain rate; monthly anomalies of likewise data; Terra MODIS mean day and night cloud cover; Terra MODIS C6 average $550 \mathrm{~nm}$ aerosol optical thickness (AOT); and NAAPS reanalysis $500 \mathrm{~nm}$ fine-mode AOT.

components. Cloud cover patterns changed over most of the region from August to September in concert with the precipitation.

Interannual anomalies for 2012 were relatively small to moderate compared to the climatological baselines. The most significant driver of interannual variability in precipitation (e.g., McBride et al., 2003), and hence biomass burning, is ENSO (e.g., Nichol, 1998; Siegert et al., 2001; Field and Shen, 2008; Reid et al., 2012). For the 2012 SWM season, the mean Oceanic Niño Index (ONI) indicated slight warming, at +0.3 to $+0.4{ }^{\circ} \mathrm{C}$ for July through October coming out of $\sim 0{ }^{\circ} \mathrm{C}$ in the boreal spring. While in a warmer phase, the burning season is still considered neutral ENSO conditions based on the commonly used $0.5^{\circ} \mathrm{C}$ threshold and in line with the climatological average fire counts observed. Reid et al. (2012) noted that there appeared to be a correlation between positive ENSO phase and earlier monsoonal transition from the southwest to the northeast phases. As is shown in the next subsection, in 2012 the monsoonal transition appeared to be consistent with this warmer ENSO phase, with northeasterly winds returning by the end of the first week of October.

Metrics for monthly meteorological anomalies were quite mixed for 2012, leading us to believe that 2012 meteorology was overall largely within the "seasonally average" domain. Indeed, given the skill of model and satellite products in the region and the paucity of rain gauge data, it is difficult to make fine delineations outside of extreme years (Reid et al., 2012, 2013). A full evaluation is out of scope here, but after evaluating a series of gauge networks, satellite, and model products (e.g., datasets found in Kalnay et al., 1996; Chen et al., 2008; Becker et al., 2013; Field et al., 2015), the consensus suggests normal precipitation and neutral drought scores in burning areas. Indeed, CMORPH precipitation was generally neutral in fire-prone areas (Fig. 3). Near-surface wind anomalies in the SCS for June through August were also generally light in the reanalysis products, although stronger monsoonal enhancements in the northern SCS were observed with resulting increases in precipitation. The most significant anomaly was seen in September, where strong but slow moving TCs clearly appear, resulting in significant flow distortions and precipitation enhancements in the SCS. September zonal anomalies maximized at $2-3 \mathrm{~m} \mathrm{~s}^{-1}$ (or $30-40 \%$ enhancement) across the SCS region at $700 \mathrm{hPa}$.

\subsubsection{Seasonal aerosol fields}

By combining fire data with meteorology, we can explain regional AOT fields for the 2012 season (Fig. 3). Smoke from biomass burning in central to southern Sumatra and Kalimantan, Borneo, mixes with pollution emissions and is transported across the South China, Sulu, and Celebes seas by the prevailing monsoonal winds (Reid et al., 2012, 2015; Wang et al., 2013; Xian et al., 2013). There, a clear gradient in AOT forms, from biomass burning in the source regions to cleaner conditions to the northeast where particles are annihilated by ever increasing probability of precipitation.

The veering of winds from southwesterly near the surface to more zonal at $700 \mathrm{hPa}$ results in off-island smoke transport being largely confined to the lowest few kilometers (Reid et al., 2015). This is clearly demonstrated in mean CALIOP extinction profiles derived in the method of Campbell et al. (2012) for a series of $5^{\circ} \times 5^{\circ}$ boxes over the AugustOctober burning period (Fig. 4, boxes marked in Fig. 3 on $550 \mathrm{~nm}$ AOT plots). Included are Sumatra and Malay Peninsula, Borneo, southern SCS, and the Sulu and Celebes seas. Results are similar to CALIOP analyses found in Campbell 


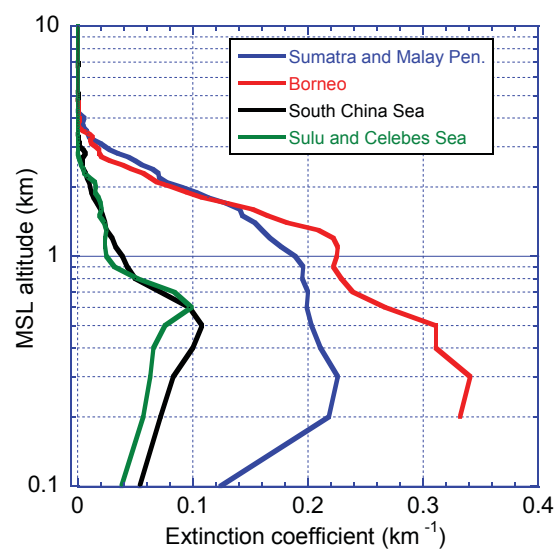

Figure 4. August-October mean CALIOP extinction coefficients for $5 \times 5^{\circ}$ boxes over southern/central Sumatra and the Malay Peninsula; south-central Borneo, the southern South China Sea, and the Sulu and Celebes seas.

et al. (2013), Reid et al. (2013), Wang et al. (2013), as well as the Singapore MPLNET climatology by Chew et al. (2013). Significant smoke concentrations are largely confined to or just above the boundary layer.

Consistent with the fire climatology of Reid et al. (2012), there is a shift in the maximum AOT in both MODIS and NAAPS from central Sumatra/Riau in August towards southern Sumatra/Sumatera Selatan in September. Advection patterns deduced from the MODIS and NAAPS products are consistent with the wind and precipitation shifts depicted in Fig. 3. Smoke is advected predominantly into northern Malay Peninsula and the central SCSs in August. As discussed in the next subsection, September showed significant variability in monsoonal strength. Regardless, overall decreased meridional winds and enhanced precipitation in the SCS from August confines the smoke largely to the southern SCS. This coincides with a shift in the domain of the Sumatran plume from over Kuala Lumpur and Penang, Malaysia, in August to centered directly over Singapore in September.

For Borneo, high AOTs are visible in two distinct lobes: eastern Kalimantan and central/western Kalimantan. The western half is clearly more dominant in August, with high AOTs spreading throughout the southern half of Borneo by September. Transport of smoke from Borneo is bifurcated by the high mountain ridge running along the border of Malaysian Sarawak and Indonesian Kalimantan (Reid et al., 2013; Wang et al., 2013). Western and some southern Kalimantan smoke exits over Sarawak into the SCS. Another lobe of smoke from southern and eastern Kalimantan exits into the Celebes Sea. Once transported off-island, smoke is advected by the southwesterly winds. As for smoke from Sumatra, the shift to a stronger zonal wind component in September leads likewise to more eastward zonal transport from Borneo.

While the AOT map gives a good semi-quantitative depiction of the overall aerosol patterns, one must be careful in evaluating AOT maps in this region. NAAPS has lower AOTs than MODIS, both in fire regions and in regard to long-range transport. These differences are the result of a number of causes, including likely cirrus contamination in the MODIS products increasing the baseline AOT throughout the region (Reid et al., 2013). At the same time, cloud cover interferes with NAAPS MODIS-derived smoke source function. There are also sampling differences inherent in a bulk monthly product to consider. For example, there are very few MODIS retrievals available for compositing (5-10 per month in the above composites shown), and when there are data they tend to be during periods of reduced convection, enhancing fire. Indeed, there are very few retrievals over land when the cloud fraction is above $30 \%$ (Hyer et al., 2011), a true anomaly in a region of such extensive cloud cover. While we expect from the nature of the data that MODIS will have consistently higher AOTs than NAAPS, there are regions where NAAPS has the higher values. These include the mountainous regions of Borneo separating Sarawak and Kalimantan. Such mountain features, up to $3 \mathrm{~km}$ high, present a physical barrier to smoke transport but are difficult to capture in model simulations - particularly at lower resolutions such as in NAAPS (Wang et al., 2013).

\subsection{Seasonal time series of fire and monsoon characteristics}

While Sect. 3.1 and Fig. 3 provide a good overview of the mean state of the monsoonal and aerosol system during the 2012 7SEAS intensive period, there is considerable highfrequency variability in fire detections and emissions. This is demonstrated in Fig. 5 for the 1 June through 31 October 2012 period, which covers nearly all of the burning activity for the 2012 SWM season. First, combined Terra and Aqua MODIS fire detections shown in Fig. 2 are broken down by key regions and time in Fig. 5a. Fire activity is demonstrated in 5-day box car average time series of combined Terra and Aqua MODIS fire hotspot data for June through October, broken down into the five key regimes defined in Reid et al. (2012, 2015): central Sumatra, southern Sumatra, Indonesian Kalimantan-Borneo (an aggregate of western, southern, and eastern Kalimantan), Malay Borneo (Sabah and Sarawak), a combined Sulawesi, Java, and Timor aggregate, and finally far-eastern Maluku and the entire island of New Guinea. Fire activity in the 2012 SWM was initiated with an event in central Sumatra in mid-June, followed by a month-long hiatus. Fire activity resumed in late July and early August in central Sumatra and Indonesian Kalimantan, subsiding somewhat in late August. The most significant burning activity occurred throughout the MC in a series of events in September through the first week of October. 


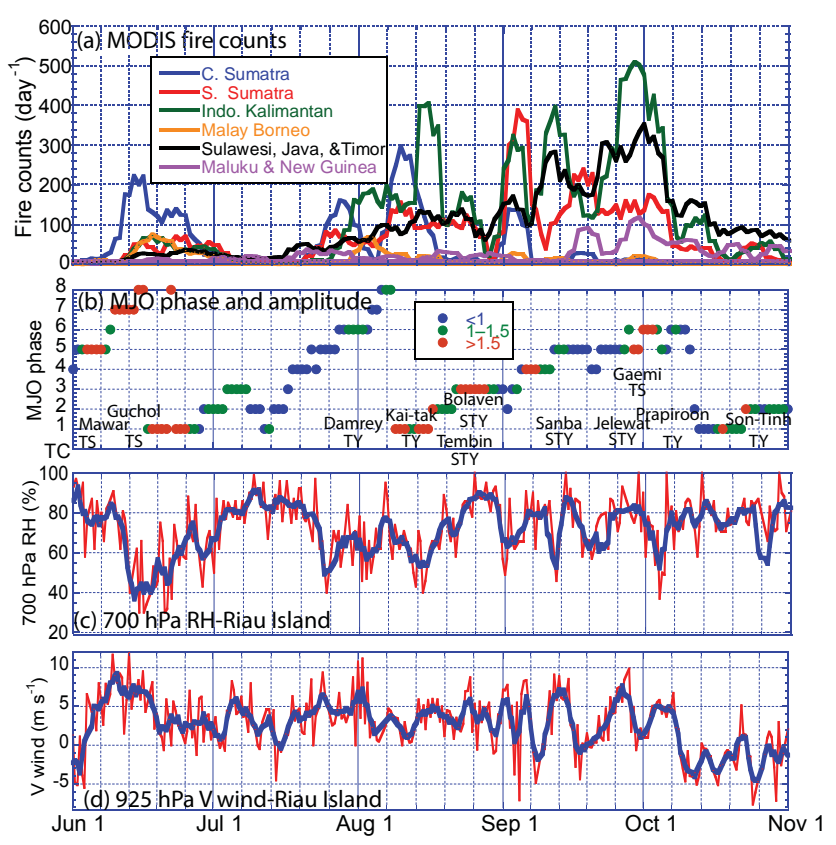

Figure 5. Time series data for the 2012 MC burning season. (a) A 5-day box car average of observed Terra and Aqua combined active fire hotspot detections for the 2012 Maritime Continent burning season by region as defined in Reid et al. (2012, 2015). (b) Wheeler index of MJO phase and color-coded amplitude, where amplitudes above one are considered statistically significant and above 1.5 as strong. Regional tropical cyclones and categories passing near Luzon are also listed (tropical storm - TS; typhoon - TY; supertyphoon - STY). (c) $700 \mathrm{hPa}$ RH from radiosondes released at Riau Island in the South China Sea as an indicator of convective activity and/or inhibition. Shown are instantaneous (red) and 3-day boxcar values (blue). (d) Likewise meridional wind at $925 \mathrm{hPa}$ at Riau Island is an indicator of monsoonal strength.

\subsubsection{Time series of ISO, fire, and monsoon characteristics for the 2012 burning season}

The episodic nature of fire activity in 2012 is related to a desire by inhabitants for burning, coupled with regional meteorological opportunity. Intraseasonal oscillations (ISOs), such as the MJO, modulate weather on 45-60-day timescales (Zhang, 2005, 2014) and have been shown to modulate aerosol life cycle across the globe's tropical and subtropical domain (Tian et al., 2011; Reid et al., 2012; Guo et al., 2013). The BSISO is similar to the MJO but with distinct northward propagation associated with the SWM (e.g., Kikuchi et al., 2012) in the northern part of the MC (north of $15^{\circ} \mathrm{N}$ ). Most of the MC is affected by its eastward propagation. As found in Reid et al. (2012) we consider the $\sim 45$-day ISO signal, as indicted by the Wheeler and Hendon (2004) MJO index, to be a dominant indicator of active convective phases and breaks (Zhang, 2005). Monsoonal strength in turn has a strong influence on fire emissions and aerosol life cycle (Reid et al., 2012) and likely AOT (Tian et al., 2008).
The Wheeler and Hendon (2004) product of MJO phase and amplitude is provided in Fig. 5b. Conventionally, the MJO exists when the amplitude is greater than 1 (above 1 standard deviation) and is considered strong when the amplitude is in excess of 1.5. To provide meteorological context for the SCS at shorter timescales, in Fig. 5b are also the names and categories of TCs entering the area (tropical storm - TS; typhoon - TY; super-typhoon - STY), timed by their closest approach to the island of Luzon, Philippines. Also, in the Fig. 5 time series, meteorological data derived from the Riau Island radiosonde site provide an indication of the state of the SWM. Included are (panel c) $700 \mathrm{hPa}$ relative humidity (RH), as an indicator of overall convective activity, and (panel d) $925 \mathrm{hPa}$ meridional $(v)$ wind component to monitor the strength and seasonal migration of the monsoon. Correlated with the meteorological parameters presented in Fig. 5 are numerous other phenomena, including the onset and length of the monsoon season (Staub et al., 2006; Cook and Buckley, 2009; Tong et al., 2009), TC activity (e.g., Maloney and Hartman, 2001), diurnal cycle of precipitation (e.g., Peatman et al., 2014), and off-island airflow. All of these factors are related to aerosol activity and transport (Reid et al., 2012, 2015; Wang et al., 2013).

If ENSO and the seasonal monsoon migration set the bounds of the burning season, the MJO often regulates the temporal variability and transport within that period. As demonstrated Fig. 5b for 2012, three ISO events propagated into the MC. Typically in the SWM, the MJO signal is weaker than in boreal winter but clearly present (Zhang, 2005, 2014). The burning season was initiated by a moderately strong event from May into early June, with amplitudes well above 1, especially for the drier phases in the MC (phases 5-8). This MJO was related to the first major burning event that emerged from central Sumatra/Riau province in June and corresponds with dry air in the lower to middle free troposphere with a seasonal low RH of $40 \%$ (Fig. 5c) and a strong monsoonal flow (Fig. 5c). This dry layer, a common feature of the MJO west of its convective center, originates from subsiding air and advected subtropical air in the Indian Ocean. It inhibits convection and hence promotes biomass burning. Indeed, central Sumatra's short pulse of fire activity in June is a recurring feature in the MODIS fire record and is likely the result of agricultural burning and stacked fuels ready for the first sufficiently dry SWM period (Reid et al., 2012). While much attention has been paid to the "anomalous" June 2013 burning and smoke event in Sumatra that severely reduced air quality on the Malay Peninsula, this event is actually a recurring feature (Reid et al., 2012), although the impacts to Singapore in 2013 were unprecedented.

The next MJO event started strong in the Indian Ocean in mid-June (phases 1 and 2), then stalled on approach to the $\mathrm{MC}$ with significant convective activity in the region. This suppressed burning activity. After a brief retreat to the west, it managed to continue to move eastward through the MC 
as a weak event that is barely recognizable in Fig. 5. Such weakening of the MJO over the MC is known as a consequence of the "barrier effect" of the MC (Zhang, 2014). Further, as discussed in Napitu et al. (2015), a weak MJO event often follows a strong event - particularly in summertime. They hypothesize that this may be a consequence of a more vigorous cooling by the previous strong MJO on sea surface temperature. As this MJO progressed to later phases, a second greater peak in August burning in central Sumatra and western Kalimantan (apparent in a peak in the greater Indonesian Kalimantan domain) appeared. As in the previous event, free tropospheric air was likewise drier and the monsoon flow steady if not significantly enhanced. This early to mid-August period typically hosts the first major event to span the MC (Reid et al., 2012) and it too is likely related to burning need and meteorological opportunity around the month of August. From August onward, the burning pattern was propagating eastward through the season, which is consistent with the eastward migration of the monsoon as described by Moron et al. (2009).

The third relevant MJO event, which also coincided with the M/Y Vasco cruise discussed in Part 2 of these papers (Reid et al., 2016), formed in the Indian Ocean in midAugust, with its amplitudes as high as 2 through early Phase 3 (its convection center entering the MC). Upon reaching the $\mathrm{MC}$ in the last week of August, however, the amplitude weakened to less than 1 (below 1 standard deviation), propagation was slow from Phase 3 to Phase 6 (the period when the MJO is transiting through the MC), and it subsequently died off in the central Pacific ocean by the end of September. Nevertheless, fire activity tracked this event, reaching a peak at the end of September. Interestingly, for this MJO, free tropospheric air was not as dry as it had been in the previous two events (Fig. 5c), perhaps related to the weak MJO dying before phases 7 and 8. Monsoonal flow was also quite unsettled in September with strong enhancements and even flow reversals. As discussed in the next subsection, monsoonal enhancements in the SCS were associated with the propagation of TCs east of the Philippines. Between these enhancements, strong reversals were found, as much as $-5 \mathrm{~m} \mathrm{~s}^{-1}$ meridional flow at Riau Island on individual soundings. These impressive reversals are consistent with easterly wave activity between TCs.

Finally, based on the meridional winds in Fig. 5d, the monsoon flow switched to the northeasterly winter phase at the end of the first week of October. This brought enhanced precipitation back to the MC and, effectively, an end to the burning season. Simultaneous with the monsoon switch, another weak and slow moving MJO event started over the Indian Ocean in October and propagated through in November (not shown). Historically, however, the monsoonal shift does not necessarily immediately bring an end to the burning season. As discussed in Reid et al. (2012) in the most significant burning years, the monsoon shift happens in the absence of significant precipitation and can even enhance burn- ing. We speculate that for 2012, more significant smoke generation and transport events advecting westward from Borneo would have been observed had this MJO progressed with more typical speed. Instead, the stalling of the MJO over the MC brought additional rainfall over the ocean (e.g., Chen and Houze, 1997; Peatman et al., 2014), further shortening aerosol lifecycles and not bringing dry air related to the lateMJO phase to the region.

\subsubsection{Tropical cyclone activity}

Throughout the above narrative is the influence of TCs which is, in part, embedded in the overall MJO and monsoonal strength signals. With the ITCZ at its most northern extent, tropical cyclone paths likewise tend to be level with or north of Luzon in early summer, descending southward as the summer progresses (Carmargo et al., 2007; Kim et al., 2008). When TCs are located just east of the Philippines or transiting westward into the SCS or up towards Japan, two significant meteorological impacts on aerosol life cycle have been hypothesized to occur (Reid et al., 2012; Wang et al., 2013). First, a long area of monsoonal enhancement akin to an inflow "arm" often forms to the south and west of the TC. This monsoon enhancement has been noted to stretch from east of the Philippines to as far west as Sumatra. Such TC-induced monsoonal enhancements have been noted by Philippine forecasters to bring heavy rainfall to Luzon (e.g., Cayanan et al., 2011; Cruz et al., 2013). Reid et al. (2012, 2015) and Wang et al. (2013) noted that such enhancements tend to draw out smoke from the MC into the SCS, where it is then sometimes annihilated by convection associated with the enhancement. However, as the TC passes, large-scale upper-level subsidence around the TC can inhibit convection and rainfall in the region, thus promoting biomass burning (and enhancing its observation from space). This subsidence can even be cross-equatorial and enhance burning activity. The balance of the TCs large-scale subsidence and monsoon flow enhancement factors in production, advection, and regional changes to precipitation allows TCs to simultaneously modulate multiple aspects of aerosol life cycle.

According to the Joint Typhoon Warming Center, the 2012 western Pacific had 25 named storms compared to 26 in the long-term average. Noteworthy is that when TCs were east of the Philippines (closest point within $1000 \mathrm{~km}$ of Luzon marked in Fig. 5b), there were often coincidences with peaks in observed SWM flow (Fig. 5d), convection (Fig. 5c), and biomass burning activity (Fig. 5a). A pair of tropical storms (Mawar and Guchol) passed directly on the eastern edge of the Philippines, just at the initiation of the burning season. A second pair of typhoons (Damrey and Kai-tak) were also associated with monsoon enhancements. The four TCs passing through the region in late August through September were particularly intense: a pair of super-typhoons (Temblin and Bolaven) in late August and two slower moving and even more intense super-typhoons (Sanba and Jelewat) passing the 
vicinity in September. The impact of these storms on the mean monthly flow and precipitation of the central SCS in of September is clear in Fig. 3. Noteworthy for the September storms was their relationship not only to regional monsoon enhancements but also with monsoon hiatuses. Indeed, as mentioned in Sect. 3.2.1 the strongest amplitude shifts in monsoonal strength for the entire 2012 burning season occurred in September when these storms were active. Strong southwesterly flow was replaced by complete flow reversals in the SCS in a matter of days (Fig. 5d). These flow reversal features are consistent with the propagation of easterly waves. Also in September, a strong tropical storm (Gaemi) formed in the SCS in late September. Aside from winds, the monsoonal enhancements from TCs resulted in the significant precipitation enhancement over the SCS in September. Between winds and precipitation, TCs clearly modulated smoke transport and scavenging.

TCs may also have played a role post-monsoon season. The monsoon shift after the first week of October occurred coincident with the arrival of Typhoon Prapiroon in the northeastern Philippines as well as category 3 Son-Tinh as it propagated across the central Philippines. Thus, while the monthly mean wind fields were relatively normal (e.g., Fig. 3), significant flow variability existed which, as we show, affected long-range aerosol transport.

\subsection{Significant smoke episodes}

Moving from burning and monsoonal activity to resultant regional AOT, 2012 showed higher burning-region AOTs in comparison to the 2011 period explored in Reid et al. (2015) and the cold and neutral ENSO phases explored in Xian et al. (2013). While satellites and models can provide regional AOT patterns, the best indicator for significant smoke events is via AOT from AERONET sites. AERONET, although spatially limited and suffering from its own clear sky bias, has the advantage of more potential samples on any given day, and an ability to quantify AOT for high concentration regions and moderately high cloud fraction. Further, through the SDA method, the fine-mode AOT of smoke and pollution can be isolated, minimizing thin cirrus contamination (Chew et al., 2011). While a full analysis of AERONET data is outside of the scope here, in Fig. 6 are the time series of finemode $500 \mathrm{~nm}$ AOTs from AERONET sites deployed for the 2012 season to provide an overview of AOT variability. Corresponding statistics for the core burning season, which we take to be 1 August through 15 October, are included in Table 2. Sites include the first AOT measurements made in the heart of the burning areas on Sumatra and Kalimantan, Borneo. To provide spatial context, for some of the most severe events corresponding NAAPS fine-mode AOTs are provided in Fig. 7.

Comparison of Fig. 6 to the temporal time series of Fig. 5a shows that fine-mode AOTs, to a certain degree, were correlated with the fire signal, but not exceedingly so. This is

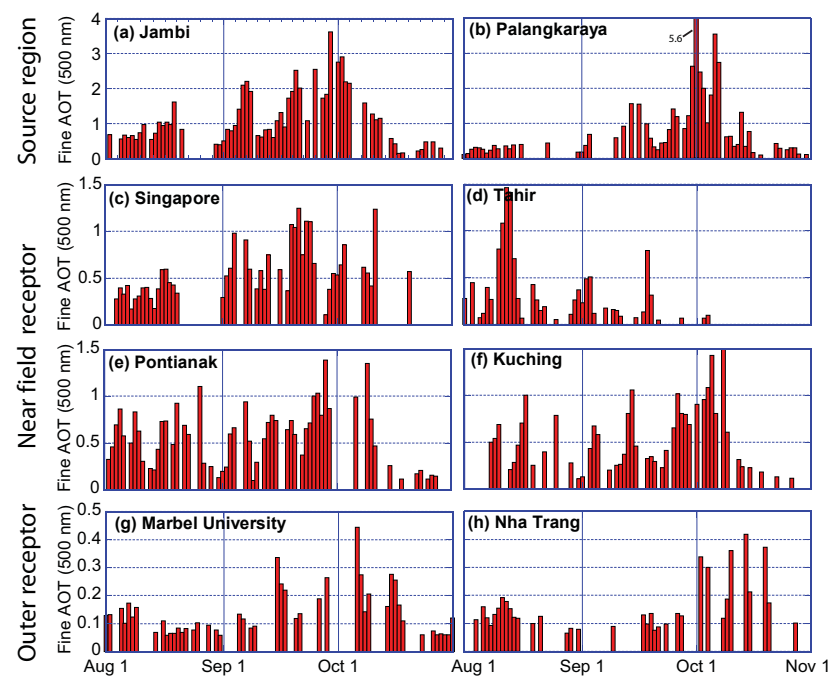

Figure 6. Daily SDA extracted fine-mode AOT from AERONET from August to October 2012. Site locations are labeled with Fig. 1. Zero values indicate data non-availability. For these sites nearly all non-available data are due to cloud cover.

perhaps due to the high coverage of cirrus clouds that can affect satellite fire observations more than AERONET observations with their SDA extraction of fine-mode AOT (e.g., see observability review by Reid et al., 2013). The weaker MJO periods or TCs may also have perturbed the transport of smoke off-island.

Using Jambi (Fig. 6a) as an indicator of Sumatran source region AOTs, smoke events were moderately strong in the early to middle month of August, reaching over 1, with a peak of 1.5. Late in August, no AOT data were available due to consistent cloud cover and precipitation, as evidenced in Fig. 3. However, Jambi AOT grew significantly coincident with southern Sumatra Burning, with AOTs being mostly over 1 from September through early October. In comparison to Jambi, (c) Singapore and (d) Tahir, both receptors for Sumatra on the Malay Peninsula, likewise showed peaks in fine AOT. Singapore was the only site operating for the midJune burning event and showed slightly elevated fine $500 \mathrm{~nm}$ AOTs, on the order of 0.5 above the 25 percentile background level of $\sim 0.3$ (not shown).

Beginning in August, Tahir in northern Malaysia appears to be a very strong receptor on 11-13 August, which may also correspond with a peak in fine AOT to 0.2 in Nha Trang, Vietnam (Fig. 6h), demonstrating long-range transport up the SCS. This is demonstrated in the NAAPS fine AOT fields for 12 August (Fig. 7a). In fact Tahir, a receptor, had higher August AOTs than Jambi, which was in the source region. As the location of Jambi was south of the Riau burning, the site may be more representative of burning in southern Sumatra. On the southern tip of the Malay Peninsula, Singapore showed higher AOTs later in the study. As shown in Figs. 3 and 5, a southward shift in burning activity on Sumatra and 


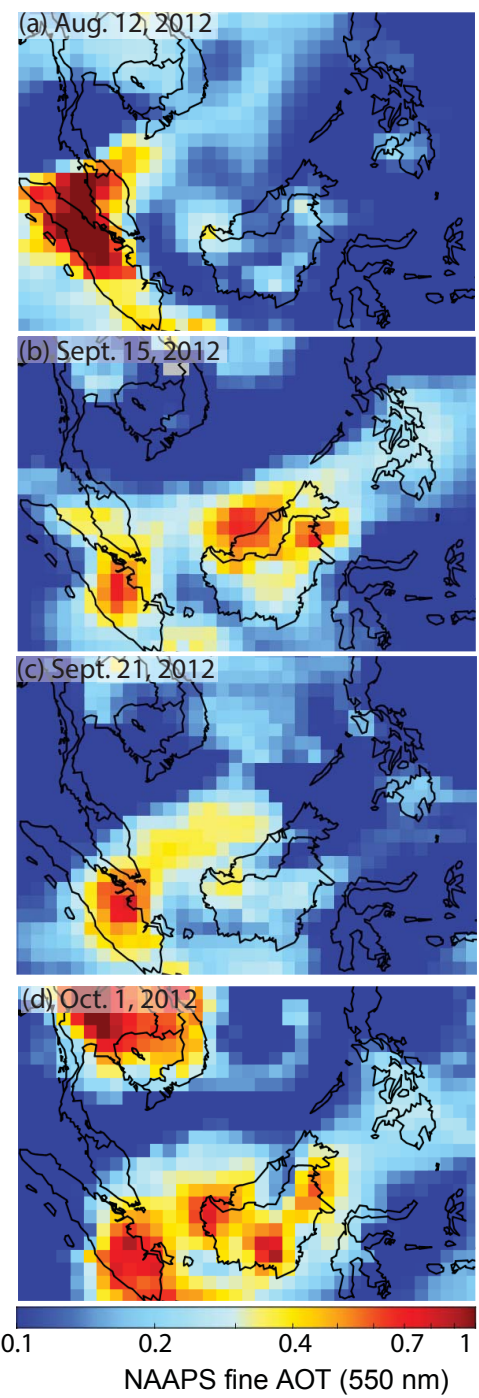

Figure 7. NAAPS fine-mode $550 \mathrm{~nm}$ AOTs for midday $(\sim 6 \mathrm{Z})$ for four significant smoke transport events.

more zonal winds brought the smoke directly over Singapore. The most significant event (21 September 2012) had AOTs reaching 1 , aided by monsoonal enhancements related to Typhoon Jelewat, with NAAPS simulating smoke transport up much of the SCS (Fig. 7c).

Using Palangkaraya as a source indicator for southern Kalimantan, the MC's largest single source region, AOT did not depart from background levels of $\sim 0.2$ until about 1 September, upon which AOTs increased significantly reaching 1.5 in mid-September, with a second event with AOTs of $\sim 5.6$ around 1 October. In comparison, for Pontianak in western Kalimantan, AOTs had a mean of 0.6 and $25-75 \%$ quartiles of $0.35-0.77$. These values were more consistent over time with only a slight enhancement in AOTs through the season. As discussed in Reid et al. (2012) and seen in the monthly average AOT plots in Fig. 3, the re- gion around Pontianak has its own burning which often follows Sumatra and thus can be regarded as a local source and a receptor. Kuching Sarawak also had a number of moderate AOT events throughout the season. Mean AOTs were 0.5 with values as high as 1.5 collinear with AOT at Palangkaraya. However, one notable event at Kuching in the middle of September peaked with an AOT of 1. Aided by monsoonal enhancement by TC Sanba exiting the region, this event at Kuching led to a subsequent peak of 0.3 at Marbel University (Fig. 6g) 2 days later. Smoke from the event was sampled by the mission Vasco cruise (Reid et al., 2016) and was simulated in NAAPS to pass through Mindanao and over the Pacific Ocean (Fig. 7b).

Burning and AOTs continued to increase through the burning seasons and dropped precipitously after the first week of October. This is coincident with large-scale flow reversal in the SCS signaling the end of the SWM (Fig. 5d). The monsoon switch, however, is not instantaneous; rather it migrates in a series of flow reversals from the north. The end result of this situation is low monsoonal winds, and very high AOTs across the region with smoke accumulating in the source regions. Pollution and smoke can also be being transported southward from peninsular Southeast Asia and China. This situation is evident with AOTs maximizing at 5 in Palangkaraya on 1 October with a second major pulse on 6 October. Likewise peaks occurred in other source and near-field receptors such as Jambi, Singapore, Kuching, and Pontianak. At the same time, AOTs began to peak at the outer receptors of Nha Trang, Vietnam, and Marbel University, Mindanao. This situation, so evident in AERONET, is regionally demonstrated in the NAAPS AOT fields for 1 October (Fig. 7d). For Nha Trang, the higher AOTs are from advection from the northwest and east, as the site was under the influence of emerging biomass burning in Indochina and pollution from China. At the same time, flow in the vicinity of Marbel University was slight and devoid of precipitation, and thus high AOTs represent some lingering burning activity from eastern Kalimantan or Sulawesi transported into the region. In particular, TC Prapiroon and Son-Tinh provided the last monsoonal enhancements in the Celebes Sea.

Perhaps the final question for a regional overview paper is, ultimately, how the smoke events (and thus likely final concentrations and particle emissions) for 2012 compare to other years. Given the complexity of observing the MC aerosol system it is difficult to be quantitative - especially in a region where fire counts alone can vary by an order of magnitude. The most reliable data are certainly AERONET, although the observing network has only recently become active in this region as part of 7SEAS. However, examination of the three sites with the longest data record is somewhat revealing. Table 3 provides mean and standard deviations of AERONET $500 \mathrm{~nm}$ fine-mode AOT for Singapore, Kuching Sarawak, and Notre Dame of Marbel University, Mindanao. Averages are for the entirety of the August through October periods as used in Fig. 7. Singapore has the longest data record, be- 


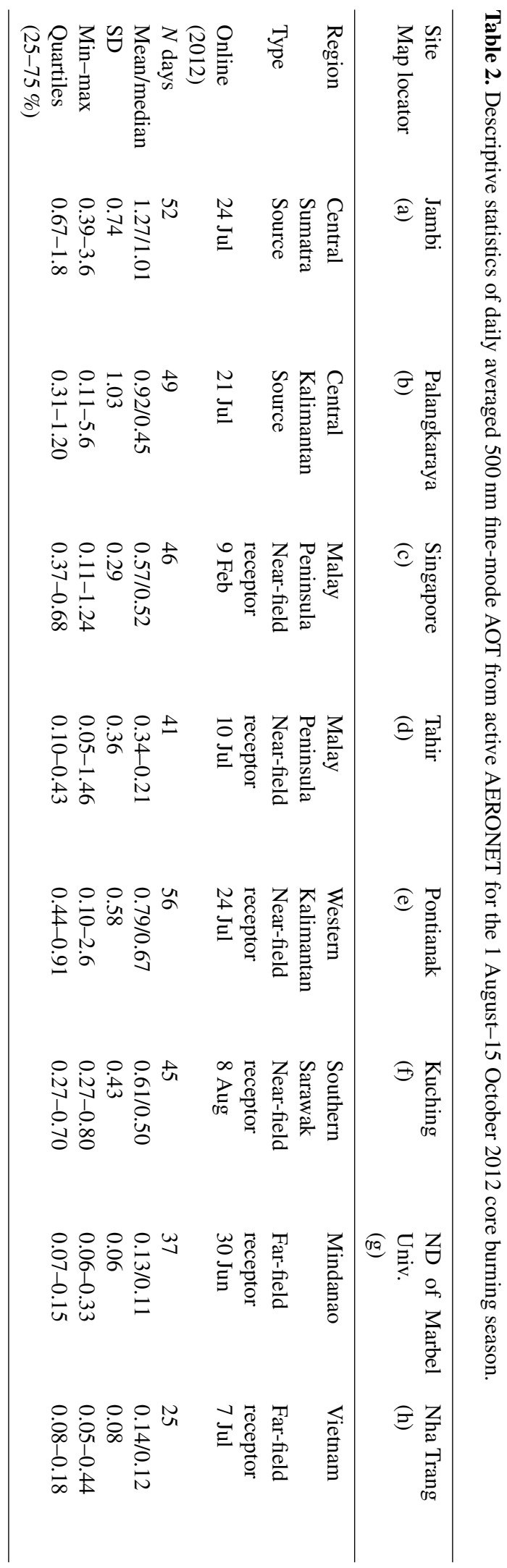

Table 3. August through October means and standard deviations of AERONET $500 \mathrm{~nm}$ fine-mode AOT for three sites with the longest data record in the Maritime Continent.

\begin{tabular}{rrrr}
\hline Year & Singapore & Kuching & ND of Marbel U. \\
\hline 2007 & $0.26 \pm 0.15$ & NA & NA \\
2008 & $0.21 \pm 0.12$ & NA & NA \\
2009 & $0.39 \pm 0.29$ & NA & NA \\
2010 & $0.27 \pm 0.29$ & NA & $0.09 \pm 0.04$ \\
2011 & $0.33 \pm 0.17$ & $0.30 \pm 0.25$ & $0.16 \pm 0.09$ \\
2012 & $0.57 \pm 0.29$ & $0.58 \pm 0.43$ & $0.14 \pm 0.08$ \\
2013 & $0.21 \pm 0.10$ & $0.29 \pm 0.19$ & $0.10 \pm 0.05$ \\
2014 & $0.56 \pm 0.36$ & NA & $0.23 \pm 0.19$ \\
2015 & $1.5 \pm 1.2$ & $1.3 \pm 1.2$ & $0.35 \pm 0.25$ \\
\hline
\end{tabular}

ing established in 2007. Interestingly, the 2012 mean of 0.57 is the second highest of the 8-year period. That of 2012 was higher than the El Niño year of 2009, yet only $40 \%$ of the 1.5 value for the massive 2015 event. This strong value is consistent with the enhanced burning activity observed in southern Sumatra in 2012. Kuching, a good receptor for smoke from Borneo, also saw the second highest AOTs of the 4 available years $(2011-2013,2015)$. However, from a fire detection point of view, both southern and eastern Kaliman$\tan$ were significantly below average. Fire activity in western Kalimantan, however, was slightly enhanced. This suggests that Kuching may be a better receptor for western Kalimantan than for the heart of Borneo's burning region. Finally for ND of Marbel University, the 2012 season was middling. This suggests it may be a receptor for smoke from southern and eastern Kalimantan, wrapping around the Celebes Sea as well as the South China Sea. Taken together, AERONET suggests that overall 2012 was a fairly significant biomass burning year, but still substantially below the massive El Niño events such as 2015, and likely 2006 and 1997.

\section{Discussion and conclusions}

The purpose of this paper is twofold. First, there is a need for a meteorological overview to support the 2012 7SEAS campaign activities. This campaign in particular was a high water mark for observations in the 7SEAS program. Here we provide seasonal plots of fire activity, monsoon characteristics, and AOT coverage to give context to measurements. In particular, we wish to support discussion of finer-scale aerosol features in Part II of this series, which focuses on ship observations in the Philippines as an indicator of the characteristics of smoke transported long distances in the South China Sea (Reid et al., 2016). A second goal of this paper is to provide an opportunity for a narrative of the complex aerosol meteorology of the MC. This narrative, when combined with the 2011 narrative in Reid et al. (2015) and brief seasonal narratives in Reid et al. (2012), allows us to gain an appreciation 
for the inter-seasonal similarities and differences in MC fire weather and smoke transport.

In regards to fire activity, there are many aspects of the 2012 season that are "typical". Overall fire hotspot detections for the core June-October burning season were only $10 \%$ under the 2003-2009 baseline provided by Reid et al. (2012), although notable regional fire perturbations include $+30 \%$ in southern Sumatra and $-40 \%$ in southern and western Kalimantan. In comparison, internal standard deviations for most regions are $>50 \%$, indicating significant spatial and temporal variation from year to year within regions. Fire activity began early in the west, in June and August, moving to the most significant burning in September and early October. This fire activity was consistent with a slightly warm but technically neutral ENSO phase, which also brought typical if not lightly enhanced precipitation.

While fire and meteorology was well within norms for "means", fire was strongly modulated by the MJO and SWM flow on Sumatra and Borneo, being more systematically increasing in eastern islands as the season progressed. This too is characteristic of regional burning activity (Reid et al., 2012). However, there were periods of strong SWM modulation brought about by a combination of TC passages (enhancing southwest flow) and easterly waves, resulting in sometimes strong meridional flow reversals. When averaged, this activity resulted in anomalously enhanced zonal winds over the central and northern South China Sea - particularly in September when burning was at a maximum. Fire activity largely subsided with the switch of the SWM to the wintertime northeasterly phase in the second week of October.

Biomass burning smoke distribution and transport were monitored by a series of AERONET sun photometers, MODIS AOT retrievals, and NAAPS reanalysis model products. For the most part, all products agree on active fire emission areas and transport patterns of smoke off the islands into the South China, Sulu, and Celebes seas by SWM winds. AERONET in particular provided the first regionwide quantitative view of AOTs. Sites within source regions, such as Jambi Sumatra and Palangkaraya, central Kalimantan, had mean and standard deviation of $500 \mathrm{~nm}$ fine AOTs of $1.3 \pm 0.7$ and $0.9 \pm 0.3$, respectively, although Palangkaraya did host the two most significant smoke events, with AOT reaching 5.6 on one day. In August, smoke largely traveled up the South China Sea to almost as far north as Luzon, Philippines. During the September peak burning period, anomalous zonal winds kept smoke to the southern South China Sea and south of central Philippines. This so happens to be the key region for the receptor measurement on the M/Y Vasco described in Part 2 of this series (Reid et al., 2016). In comparison to other years in the AERONET data record (going back as far as 2007 for Singapore), 2012 was clearly a substantial year, with heavy smoke over much of the region, exceeding other years with the notable exception of the 2015 El Niño event. This is somewhat at odds with MODIS active fire hotspot data which suggested more average fire activity.
Overall 2012 fire activity and transport patterns were well within " $1 \sigma$ " for SWM. However, the standard deviations for fire and smoke activity for the region are exceptionally large. Qualitatively, from a fire and smoke closure point of view, there are consistencies in the dataset. Significant fire activity and high AOTs were observed in southern Sumatra, Singapore, and Tahir, Malaysia, as a receptor. However, burning on Borneo was generally neutral or slightly enhanced in the west and $45 \%$ lower than average in the core areas of southern and western Kalimantan. AOTs at Kuching, an excellent indicator of smoke entering the South China Sea, were high. The complexity of the MC's meteorology and aerosol system results in nonlinear relations between observed fire activity and regional aerosol loading. Previously identified aspects of the system such as monsoonal shifts, the MJO/BSISO, TCs, and the role of orography follow the conceptual modes and examples of Reid et al. (2012) and Wang et al. (2013). However, as of yet, observability and predictability of the system are nevertheless still only semi-quantitative. Clearly, the 2012 field measurement dataset, especially in the context of its 2011 preparatory mission, is valuable for further study.

\section{Data availability}

Data used in this analysis are all derived from public data sources. NASA MODIS fire and AOT data were obtained from the NASA LAADS ftp site: ftp://ladsweb. nascom.nasa.gov/. NASA AERONET data are available from the AERONET website: http://aeronet.gsfc.nasa.gov/. Navy NAAPS aerosol reanalysis and meteorology data are available at the US GODAE server: http://www.usgodae. org/. Finally, radiosonde data were extracted from the University of Wyoming radiosonde data repository: http: //weather.uwyo.edu/upperair/sounding.html.

Acknowledgements. We are grateful to all participants of the 2012 7SEAS intensive study and are in particular to the host institutions for regional AERONET site deployment and the use of derived optical thickness data herein. Authors also benefitted from conversations with Eric Maloney (CSU), Matthew Wheeler (CSIRO), and Chidong Zhang (U of Miami). Funding for US scientist deployment and instrument analysis was provided by the NRL Base Program and ONR 35. Modeling analysis was provided by ONR 32. Remote sensing and model analysis was provided by the NASA Interdisciplinary Science Program. Ground site deployments were supported by the NASA Radiation Science Program through a grant from the Southeast Asia Composition, Cloud, Climate Coupling Regional Study (SEAC ${ }^{4} \mathrm{RS}$ ) science team. Author James R. Campbell acknowledges the support of NASA Interagency Agreement NNG13HH10I on behalf of MPLNET and SEAC ${ }^{4}$ RS science teams.

Edited by: F. Yu

Reviewed by: R. Swap and two anonymous referees 


\section{References}

Atwood, S. A., Reid, J. S., Kreidenweis, S. M., Yu, L. E., Salinas, S. V., Chew, B. N., and Balasubramanian, R.: Analysis of source regions for smoke events in Singapore for the 2009 El Niño burning season, Atmos. Environ., 78, 219-230, doi:10.1016/j.atmosenv.2013.04.047, 2013.

Atwood, S. A., Reid, J. S., Kreidenweis, S. M., Blake, D. R., Jonsson, H. H., Lagrosas, N. D., Lynch, P., Reid, E. A., Sessions, W. R., and Simpas, J. B.: Size-resolved aerosol and cloud condensation nuclei $(\mathrm{CCN})$ properties in the remote marine South China Sea, Part 1: Observations and source classification, Atmos. Chem. Phys. Discuss., doi:10.5194/acp-2016-645, in review, 2016.

Becker, A., Finger, P., Meyer-Christoffer, A., Rudolf, B., Schamm, K., Schneider, U., and Ziese, M.: A description of the global land-surface precipitation data products of the Global Precipitation Climatology Centre with sample applications including centennial (trend) analysis from 1901-present, Earth Syst. Sci. Data, 5, 71-99, doi:10.5194/essd-5-71-2013, 2013.

Campbell, J. R., Reid, J. S., Westphal, D. L., Zhang, J., Tackett, J. L., Chew, B. N., Welton, E. J., Shimizu A., and Sugimoto, N.: Characterizing aerosol particle composition and the vertical profile of extinction and linear depolarization over Southeast Asia and the Maritime Continent: the 2007-2009 view from CALIOP, Atmos. Res., 122, 520-543, doi:10.1016/j.atmosres.2012.05.007, 2013.

Campbell, J. R., Ge, C., Wang, J., Welton, E. J., Bucholtz, A., Hyer, E. J., Reid, E. A., Chew, B. N., Liew, S.-C., Salinas, S. V., Lolli, S., Kaku, K. C., Lynch, P., Mahamud, M., Mohamad, M., and Holben, B. N.: Applying advanced ground-based remote sensing in the Southeast Asian Maritime Continent to characterize regional proficiencies in smoke transport modeling, J. Appl. Meteorol. Clim., 55, 3-22, doi:10.1175/JAMC-D-15-0083.1., 2016.

Carmargo, S. J., Robertson, A. W., Gaffnew, S. J., Smyth, P., and Ghil, M.: Cluster analysis of typhoon tracks. Part 1. General properties, J. Climate, 20, 3635-3653, 2007.

Cayanan, E. O., Chen, T.-C, Argete, J. C., Yen, M.-C., and Nilo, P. D.: The effect of tropical cyclones on southwest monsoon rainfall in the Philippines, J. Meteorol. Soc. Jpn, 89A, 123-139, 2011.

Chang, C.-P., Wang, Z., Mcbride, J., and Liu, C.-H.: Annual cycle of Southeast Asia-Maritime Continent rainfall and asymmetric monsoon transition, J. Climate, 18, 287-301, 2005.

Chen, M. Y., Shi, W., Xie, P. P., Silva, V. B. S., Kousky, V. E., Higgins, R. W., and Janowiak, J. E.: Assessing objective techniques for gauge-based analyses of global daily precipitation, J. Geophys. Res., 113, D04110, doi:10.1029/2007JD009132, 2008.

Chen, S. S. and Houze, R. A.: Diurnal variation and life-cycle of deep convective systems over the tropical Pacific warm pool, Q. J. Roy. Meteor. Soc., 123, 357-388, 1997.

Chew, B. N., Campbell, J. R., Reid, J. S., Giles, D. M., Welton, E. J., Salinas, S. V., and Liew, S. C.: Tropical cirrus cloud contamination in sun photometer data, Atmos. Environ., 45, 6724-6731, doi:10.1016/j.atmosenv.2011.08.017, 2011.

Chew, B. N., Campbell, J. R., Salinas, S. V., Chang, C. W., Reid, J. S., Welton, E. J., Holben, B. N., and Liew, S. C.: Aerosol particle vertical distributions and optical properties over Singapore, Atmos. Environ., 79, 599-613, doi:10.1016/j.atmosenv.2013.06.026, 2013.
Cook, B. I. and Buckley, B. M.: Objective determination of monsoon season onset, withdrawal, and length, J. Geophys. Res., 114, D23109, doi:10.1029/2009JD012795, 2009.

Cruz, F. T., Narisma, G. T., Villafuerte, M. Q., Cheng Chua, K. U., and Olaguera, L. M.: A climatological analysis of the southwest monsoon rainfall in the Philippines, Atmos. Res., 122, 609-616, doi:10.1016/j.atmosres.2012.06.010, 2013.

Field, R. D. and Shen, S. S. P.: Predictability of carbon emissions from biomass burning in Indonesia, J. Geophys. Res., 113, G04024, doi:10.1029/2008JG000694, 2008.

Field, R. D., Spessa, A. C., Aziz, N. A., Camia, A., Cantin, A., Carr, R., de Groot, W. J., Dowdy, A. J., Flannigan, M. D., Manomaiphiboon, K., Pappenberger, F., Tanpipat, V., and Wang, X.: Development of a Global Fire Weather Database, Nat. Hazards Earth Syst. Sci., 15, 1407-1423, doi:10.5194/nhess-151407-2015, 2015.

Ge, C., Wang, J., and Reid, J. S.: Mesoscale modeling of smoke transport over the Southeast Asian Maritime Continent: coupling of smoke direct radiative effect below and above the low-level clouds, Atmos. Chem. Phys., 14, 159-174, doi:10.5194/acp-14159-2014, 2014.

Giorgi, F., Coppola, E., Solomon, F., Mariotti, L., Sylla, M. B., Bi, X., Elguindi, N., Diro, G. T., Nair, V., Giuliani, G., Turuncoglu, U. U., Cozzini,S., Guttler, I., O’Brien, T. A., Tawfik, A. B., Shalaby, A., Zakey, A. S., Steiner, A. L., Stordal, F., Sloan, L. C., and Brankovic, C.: RegCM4: model description and preliminary tests over multiple CORDEX domains, Clim. Res., 52, 7-29, 2012.

Guo, Y. J., Tian, B., Kahn, R. A., Kalashnikova, O., Wong, S., and Waliser, D. E.: Tropical Atlantic dust and smoke aerosol variations related to the Madden-Julian Oscillation in MODIS and MISR observations, J. Geophys. Res., 118, 4947-4963, doi:10.1002/jgrd.50409, 2013.

Holben, B. N., Eck, T. F., Slutsker, I., Tanre, D., Buis, J. P., Setzer, A., Vermote, E., Reagan, J. A., Kaufman, Y. J., Nakajima, T., Lavenu, F., Jankowiak, I., and Smirnov, A.: AERONET - A federated instrument network and data archive for aerosol characterization, Remote Sens. Environ., 66, 1-16, 1998.

Hogan, T. F. and Rosmond, T. E.: The description of the U.S. Navy Operational Global Atmospheric Prediction System's spectral forecast model, Mon. Weather Rev., 119, 1786-1815, 1991.

Hyer, E. J. and Chew, B. N.: Aerosol transport model evaluation of an extreme smoke episode in Southeast Asia, Atmos. Environ., 44, 1422-1427, doi:10.1016/j.atmosenv.2010.01.043, 2010.

Hyer, E. J., Reid, J. S., and Zhang, J.: An over-land aerosol optical depth data set for data assimilation by filtering, correction, and aggregation of MODIS Collection 5 optical depth retrievals, Atmos. Meas. Tech., 4, 379-408, doi:10.5194/amt-4-379-2011, 2011.

Hyer, E. J., Reid, J. S., Prins, E. M., Hoffman, J. P., Schmidt, C. C., Miettinen, J. I., and Giglio, L.: Patterns of fire activity over Indonesia and Malaysia from polar and geostationary satellite observations, Atmos. Res., 122, 504-519, doi:10.1016/j.atmosres.2012.06.011, 2013.

Jamandre, C. A. and Narisma, G. T.: Spatio-temporal validation of satellite-based rainfall estimates in the Philippines, Atmos. Res., 122, 599-608, doi:10.1016/j.atmosres.2012.06.024, 2013.

Joyce, R. J., Janowiak, J. E., Arkin, P. A., and Xie, P.: CMORPH: A method that produces global precipitation estimates from passive 
microwave and infrared data at high spatial and temporal resolution, J. Hydrometeorol., 5, 487-503, 2004.

Kaku, K. C., Reid, J. S., O’Neill, N. T., Quinn, P. K., Coffman, D. J., and Eck, T. F.: Verification and application of the extended spectral deconvolution algorithm (SDA+) methodology to estimate aerosol fine and coarse mode extinction coefficients in the marine boundary layer, Atmos. Meas. Tech., 7, 3399-3412, doi:10.5194/amt-7-3399-2014, 2014.

Kalnay, E., Kanamitsu, M., Kistler, R., Collins, W., Deaven, D. L., Iredell, M., Saha, S., White, G., Woollen, J., Zhu, Y., Leetmaa, A., Reynolds, R., Chelliah, M., Ebisuzaki, W., Higgins, W., Janowiak, J., Mo, K. C., Ropelewski, C., Wang, J., Jenne, R., and Joseph, D.: The NCEP/NCAR 40-year reanalysis project, B. Am. Meteorol. Soc., 77, 437-470, 1996.

Kikuchi, K., Wang, B., and Kajikawa, Y.: Bimodal representation of the tropical intraseasonal oscillation, Clim. Dynam., 38, 19892000, doi:10.1007/s00382-011-1159-1, 2012.

Kim, J. H., Chang, C. H., Kim, H. S., Sui, C.-H., and Park, S. K.: Systematic variation of summertime tropical cyclone activity in the Western North Pacific in relation to the Madden-Julian Oscillation, J. Climate, 21, 1171-1191, doi:10.1175/2007JCLI1493.1, 2008.

Levy, R. C., Mattoo, S., Munchak, L. A., Remer, L. A., Sayer, A. M., Patadia, F., and Hsu, N. C.: The Collection 6 MODIS aerosol products over land and ocean, Atmos. Meas. Tech., 6, 29893034, doi:10.5194/amt-6-2989-2013, 2013.

Lin, N.-H., Si-Chee Tsay, S.-C., Maring, H. B., Yen, M.-C. Sheu, G.-R., Wang, S.-H., Chi, K.-H., Chuang, M.-T., Ou-Yang, C.-F., Fu, J. S., Reid, J. S., Lee, C.-T., Wang, L.-C., Wang, J.-L., Hsu, C. N., Sayer, A. M., Holben, B. N., Yu-Chi Chu, Y.-C., Nguyen, X. A., Sopajaree, K., Chen, S.-J., Cheng, M.-T., Tsuang, B. J., Tsai, C.-J., Peng, C.-M., Schnell, R. C., Conway, T., Chang, C.-T., Lin, K.-S., Tsai, Y. I., Lee, W.-J., Chang, S.-C., Liu, J.J., Chiang, W.-L., Huang, S.-J., Lin, T.-H., and Liu, G. R.: An overview of regional experiments on biomass burning aerosols and related pollutants in Southeast Asia: From BASE-ASIA and the Dongsha Experiment to 7-SEAS, Atmos. Environ., 78, 1-19, doi:10.1016/j.atmosenv.2013.04.066, 2013.

Lu, E. and Chan, J. C. L.: A unified monsoonal index for South China, J. Climate, 12, 2375-2385, 1999.

Lynch, P., Reid, J. S., Westphal, D. L., Zhang, J., Hogan, T. F., Hyer, E. J., Curtis, C. A., Hegg, D. A., Shi, Y., Campbell, J. R., Rubin, J. I., Sessions, W. R., Turk, F. J., and Walker, A. L.: An 11-year global gridded aerosol optical thickness reanalysis (v1.0) for atmospheric and climate sciences, Geosci. Model Dev., 9, 14891522, doi:10.5194/gmd-9-1489-2016, 2016.

Maloney, E. D. and Hartman, D. L.: The Madden Julian oscillation, barotropic dynamics, and the North Pacific tropical cyclone formation, part 1: Observations, J. Atmos. Sci., 58, 2545-2558, 2001.

McBride, J. L., Malcolm, R., and Haylock, N. N.: Relationships between the Maritime Continent heat source and the El NiñoSouthern Oscillation phenomenon, J. Climate, 16, 2905-2914, 2003.

Miller, S. D., Hawkins, J. D., Kent, J., Turk, F. J., Lee, T. F., Kuchiauskas, A. P., Richardson, K., Wade, R., and Hoffman, C.: NexSat: Previewing NPOESS/VIIRS imagery capabilities, B. Am. Meteorol. Soc., 87, 433-446, doi:10.1175/BAMS-87-4-433, 2006.
Misra, V. and Li, H.: The seasonal predictability of the Asian summer monsoon in a two tiered forecast system, Clim. Dynam., 42, 2491-2507, doi:10.1007/s00382-013-1838-1, 2014.

Moron, V., Robertson, A. W., and Beer, R.: Spatial coherence and seasonal predictability of monsoon onset over Indonesia, J. Climate, 22, 840-850, 2009.

Napitu, A. M., Gordon, A. L., and Pujiana, K.: Intraseasonal sea surface temperature Variability across the Indonesian Sea, J. Climate, 28, 8710-8727, 2015.

Nichol, J.: Smoke haze in Southeast Asia: A predictable recurrence, Atmos. Environ., 32, 2715-2716, 1998.

O’Neill, N. T., Eck, T. F., Smirnov, A., Holben, B. N., and Thulasiraman, S.: Spectral discrimination of coarse and fine mode optical depth, J. Geophys. Res., 108, 4559, doi:10.1029/2002JD002975, 2003.

Peatman, S. C., Mathews, A. J., and Stevens, D. P.: Propagation of the Madden-Julian Oscillation through the Maritime Continent and scale interaction with the diurnal cycle of precipitation, Q. J. Roy. Meteor. Soc., 140, 814-825, doi:10.1002/qj.2161, 2014.

Reid, J. S., Hyer, E. J., Prins, E. M., Westphal, D. L., Zhang, J. L., Wang, J., Christopher, S. A., Curtis, C. A., Schmidt, C. C., Eleuterio, D. P., Richardson, K. A., and Hoffman, J. P.: Global Monitoring and Forecasting of Biomass-Burning Smoke: Description of and Lessons From the Fire Locating and Modeling of Burning Emissions (FLAMBE) Program, IEEE J. Sel. Top. Appl., 2, 144-162, doi:10.1109/JSTARS.2009.2027443, 2009.

Reid, J. S., Xian, P., Hyer, E. J., Flatau, M. K., Ramirez, E. M., Turk, F. J., Sampson, C. R., Zhang, C., Fukada, E. M., and Maloney, E. D.: Multi-scale meteorological conceptual analysis of observed active fire hotspot activity and smoke optical depth in the Maritime Continent, Atmos. Chem. Phys., 12, 2117-2147, doi:10.5194/acp-12-2117-2012, 2012.

Reid, J. S., Hyer, E. J., Johnson, R. S., Holben, B. N., Yokelson, R. J., Zhang, J., Campbell, J. R., Christopher, S. A., Di Girolamo, L., Giglio, L., Holz, R. E., Kearney, C., Miettinen, J., Reid, E. A., Turk, F. J., Wang, J., Xian, P., Zhao, G., Balasubramanian, R., Chew, B. N., Janjai, S., Lagrosas, N., Lestari, P., Lin, N. H., Mahmud, M., Nguyen, A. X., Norris, B., Oanh, N. T. K., Oo, M., Salinas, S. V., Welton, E. J., and Liew, S. C.: Observing and understanding the Southeast Asian aerosol system by remote sensing: An initial review and analysis for the Seven Southeast Asian Studies (7SEAS) program, Atmos. Res., 122, 403-468, doi:10.1016/j.atmosres.2012.06.005, 2013.

Reid, J. S., Lagrosas, N. D., Jonsson, H. H., Reid, E. A., Sessions, W. R., Simpas, J. B., Uy, S. N., Boyd, T. J., Atwood, S. A., Blake, D. R., Campbell, J. R., Cliff, S. S., Holben, B. N., Holz, R. E., Hyer, E. J., Lynch, P., Meinardi, S., Posselt, D. J., Richardson, K. A., Salinas, S. V., Smirnov, A., Wang, Q., Yu, L., and Zhang, J.: Observations of the temporal variability in aerosol properties and their relationships to meteorology in the summer monsoonal South China Sea/East Sea: the scale-dependent role of monsoonal flows, the Madden-Julian Oscillation, tropical cyclones, squall lines and cold pools, Atmos. Chem. Phys., 15, 1745-1768, doi:10.5194/acp-15-1745-2015, 2015.

Reid, J. S., Lagrosas, N. D., Jonsson, H. H., Reid, E. A., Atwood, S. A., Boyd, T. J., Ghate, V. P., Xian, P., Posselt, D. J., Simpas, J. B., Uy, S. N., Zaiger, K., Blake, D. R., Bucholtz, A., Campbell, J. R., Chew, B. N., Cliff, S. S., Holben, B. N., Holz, R. E., Hyer, E. J., Kreidenweis, S. M., Kuciauskas, A. P., Lolli, S., Oo, M., Perry, 
K. D., Salinas, S. V., Sessions, W. R., Smirnov, A., Walker, A. L., Wang, Q., Yu, L., Zhang, J., and Zhao, Y.: Aerosol meteorology of Maritime Continent for the 2012 7SEAS southwest monsoon intensive study - Part 2: Philippine receptor observations of finescale aerosol behavior, Atmos. Chem. Phys., 16, 14057-14078, doi:10.5194/acp-16-14057-2016, 2016.

Salinas, S. V., Chew, B. N., Mohamad, M., Mahmud, M., and Liew, S. C.: First measurements of aerosol optical depth and Angstrom exponent number from AERONET's Kuching site, Atmos. Environ., 78, 231-241, doi:10.1016/j.atmosenv.2013.02.016, 2013.

Sampson, C. R. and Schrader A. J.: The Automated Tropical Cyclone Forecasting System (Version 3.2), B. Am. Meteorol. Soc., 81, 1231-1240, 2000.

Siegert, F., Ruecker, G., Hinrichs A., and Hoffmann A. A.:. Increased damage from fires in logged forests during droughts caused by El Niño, Nature, 414, 437-440, 2001.

Staub, K. H., Kilandis, G. N., and Ciesielski, P. E.: The role of equatorial waves in the onset of the South China Sea summer monsoon and the demise of the El Niño during, 1998, Dynam. Atmos. Oceans, 42, 216-238, doi:10.1016/j.dynatmoce.2006.02.005, 2006.

Tian, B., Waliser, D. E., Kahn, R. A., Li, Q., Yung, Y. L., Tyranowski, T., Geogdzhayev, I. V., Mishchenko, M. I., Torres, O., and Smirnov, A.: Does the Madden-Julian Oscillation influence aerosol variability?, J. Geophys. Res., 113, D12215, doi:10.1029/2007JD009372, 2008.

Tian, B., Waliser, D. E., Kahn, R. A., and Wong, S.: Modulation of Atlantic aerosols by the Madden-Julian Oscillation, J. Geophys. Res., 116, D15108, doi:10.1029/2010jd015201, 2011.

Tong, H. W., Chan, J. C. L., and Zhou, W: The role of the MJO and mid-latitude fronts in the South China Sea Summer monsoon onset, Clim. Dynam., 33, 827-841, doi:10.1007/s00382-008-04907, 2009.

Wang, J., Gei, C., Yang, Z., Hyer, E., Reid, J. S., Chew, B. N., and Mahmud, M.: Mesoscale modeling of smoke transport over the South Asian maritime continent: vertical distributions and topographic effect, Atmos. Res., 122, 486-503, 2013.
Wheeler, M. C. and Hendon, H. H.: An all-season real-time multivariate MJO index: Development of an index for monitoring and prediction, Mon. Weather Rev., 132, 1917-1932, 2004.

Wu, P., Hara, M., Hamada, J.-I., Yamanaka, M. D., and Kimura, F.: Why a large amount of rain falls over the sea in the vicinity of western Sumatra island during nighttime, Appl. Meteorol., 48, 1345-1361, doi:10.1175/2009JAMC2052.1, 2009.

Xian, P., Reid, J. S., Turk, J. F., Hyer, E. J., and Westphal D. L.: Impact of modeled versus satellite measured tropical precipitation on regional smoke optical thickness in an aerosol transport model, Geophys. Res. Lett., 36, L16805, doi:10.1029/2009GL038823, 2009.

Xian, P., Reid, J. S., Atwood, S. A., Johnson, R., Hyer, E. J., Westphal, D. L., and Sessions, W.: Smoke transport patterns over the Maritime Continent, Atmos. Res., 122, 469-485, doi:10.1016/j.atmosres.2012.05.006, 2013.

Yang, L., Nguyen, D. M., Jia, S. H., Reid, J. S., and Yu, L. E.: Impacts of biomass burning smoke on the distributions and concentrations of $\mathrm{C}_{2}-\mathrm{C}_{5}$ dicarboxylic acids and dicarboxylates in a tropical urban environment, Atmos. Environ., 78, 211-218, doi:10.1016/j.atmosenv.2012.03.049, 2013.

Zhang, C.: Madden-Julian Oscillation, Rev. Geophys., 43, RG2003, doi:10.1029/2004RG000158, 2005.

Zhang, C.: Madden-Julian Oscillation: Bridging Weather and Climate, B. Am. Meteorol. Soc., 94, 1849-1870, doi:10.1175/BAMS-D-12-00026.1, 2014.

Zhang, J. L., Reid, J. S., Westphal, D. L., Baker, N. L., and Hyer, E. J.: A system for operational aerosol optical depth data assimilation over global oceans, J. Geophys. Res.-Atmos., 113, D10208, doi:10.1029/2007JD009065, 2008. 